\title{
ДУАЛИЗМ ИСПОЛНИТЕЛЬНОЙ ВЛАСТИ: КОНСТИТУЦИОННЫЕ ПРЕДПОСЫЛКИ И СРЕДСТВА ОГРАНИЧЕНИЯ
}

\begin{abstract}
Аннотация: Раскрывается сущность и выделяются разновидности дуализма государственной власти как конституцчионого распределения функций и полномочий по ее осуществлению между двумя высшими органами государства. Анализируется проблема дуализма исполнительной власти как конституционного распределения полномочий по ее осуществлению между президентом и правительством. На основании анализа особенностей президентской, парламентарной и смешанной форм республиканского правления выделяются конституционные предпосылки дуализма исполнительной власти: отсутствие в конституциии определения главы исполнительной власти и наделение президента значительными полномочиями по ее осуществлению. Обращчается внимание на отрицательные с точки зрения эффективности осуществления государственной власти последствия дуализма исполнительной власти в виде потенциальных противоречий и конфликтов в отношениях между президентом и правительством (премьер-министром). Выделяются возможные конституциионые средства преодоления или ограничения дуализма исполнительной власти: провозглашение президента главой исполнительной власти с подчинением ему правительства (президентская республика); институт контрасигнации актов президента премьер-министром и министрами, ответственными за их исполнение (парламентарная республика); институт политической ответственности правительства перед президентом с возможностью отставки премьер-министра по решению президента и институт контрасигнации (смешанная республика). Определяется общее направление преодоления дуализма исполнительной власти в процессе перехода от президентско-парламентарной к парламентарно-президентской форме правления-значительное ограничение полномочий президента в сфере исполнительной власти. Основные методы исследования: контент-анализ, сравнительно-правовой анализ. Метод контент-анализа применяется для формализованного исследования содержания текстов конституций различных государств с изелью выделения в них норм и институтов как порождающих дуализм исполнительной власти, так и способствуюших его преодолению или ограничению. Метод сравнительно-правового анализа используется для сравнительного исследования особенностей различных форм республиканского правления под углом зрения свойственных им таких конституциионных норм и институтов. Научная новизна статьи состоит в постановке проблемы отрицательных последствий дуализма исполнительной власти, выделении и анализе его конституционных предпосылок и средств преодоления или ограничения при различных формах республиканского правления, в том числе в условиях учрежденной в Украине смешанной республики. Автор приходит к выводам, что дуализм исполнительной власти, как конституционное распределение полномочий по ее осуществлению между президентом и правительством, противоречит централизованному характеру этой власти и может порождать противоречия и конфликты между президентом и правительством (премьер-министром), отрицательно влияющце на эффективность государственной власти. В президентской республике дуализм исполнительной власти не допускается конституционным провозглашением президента главой исполнительной власти и подчинением ему правительства. В парламентарной республике конституциионным средством ограничения дуализма исполнительной власти (реальных полномочий президента) является институт контрасигнации. Общим направлением преодоления дуализма исполнительной власти в смешанной республике является ограничение конституционных полномочий президента по ее осуществлению. Конкретными конституционныли средствами преодоления или ограничения дуализма исполнительной власти в смешанной республике являются институт политической ответственности правительства перед президентом с возможностью отставки премьер-министра по решению президента и институт контрасигнации с правом премьер-министра контрасигновать акты президента по своему усмотрению.
\end{abstract}

Ключевые слова: Дуализм власти, дуализм исполнительной власти, президент, правительство, премьер-министр, президентсткая республика, парламентарная республика, смешанная республика, сдержки и противовесы, контрасигнация.

Abstract: This article reveals the essence and highlights the various types of dualism of the government as a constitutional distribution of functions and authority between two highest branches of government. Based on the analysis of the specificity of the presidential, parliamentary, and semi-presidential form of republican government the author underlines 


\section{Право и политика $6(186) \cdot 2015$}

the constitutional prerequisites of dualism of the executive branch: absence of definition of the head of executive branch in the constitution, and endowment of the president with significant authority. This work accentuates the possible constitutional means of overcoming or limiting dualism of the executive branch: declaration of the president as the head of the executive branch with authority over the government (presidential system); institution of countersignature of acts of president by the prime minister and the cabinet of ministers responsible for their execution (parliamentary system); institution of political responsibility of the government before president with the ability to dismiss the prime minister by the presidential order and the institution of countersignature (semi-presidential system). The author concludes that dualism of executive branch, same as constitutional distribution of authority between president and the government, contradicts the centralized character of this authority and can cause disputes and conflict between the president and the government (prime minister), negatively affection the efficiency of government administration.

Keywords: Semi-presidential system, parliamentary republic, presidential republic, prime minister, government, president, dualism of executive power, dualism of power, check and balance system, countersignature.

П од дуализмом (от лат. dualis - двойственный) власти в конституционно-правовой науке понимается «распределение полномочий по осуществлению государственной власти между двумя высшими органами государства при отсутствии между ними тесных функциональных отношений» [1, с.134]. Дуализм власти может существовать как в государстве в целом, так и в отдельной ветви государственной власти. Он имманентно присущ таким формам государственного правления как дуалистическая монархия и президентская республика в ее классическом виде. В дуалистической монархии функции и полномочия по осуществлению государственной власти распределяются между монархом и парламентом, в президентской республике, которую называют еще дуалистической, - между президентом и парламентом.

В Иране дуализм власти существует на уровне главы государства - его функции и полномочия распределяются между светским Президентом и духовным Руководителем. В некоторых странах существует дуализм законодательной власти: функции и полномочия по ее осуществлению распределяются между парламентом и т.н. надпарламентским органом власти - особым представительским учреждением, которое периодически созывается для принятия наиболее важных государственных решений (Великое Народное Собрание в Болгарии, Великий Народный Хурал в Монголии, Халк Маслахаты в Туркменистане, Народный Консультативный Конгресс в Индонезии).

Дуализм власти усложняет ее функционирование, может приводить к противостоянию органов государственной власти, поэтому должен конституционно тем или иным образом ограничиваться. Такое ограничение достигается различными путями: доминированием монарха над парламентом (дуалистическая монархия), сбалансированностью полномочий президента и парламента в системе сдержек и противовесов (президентская республика), осуществлением Президентом полномочий за пределами компетенции Руководителя (Иран), четким разграничением сфер компетенции парламента и надпарламентского органа власти и функционированием последнего на непостоянной основе.

В системе судебной власти дуализм невозможен в принципе, поскольку она по самой своей природе полицентрична - в ней каждый суд осуществляет правосудие самостоятельно, независимо от других судов и каких бы то ни было иных государственных органов. В судебной системе отсутствует какая бы то ни была иерархия: суды высшей инстанции могут пересматривать решения судов низшей инстанции только в апелляционном или кассационном порядке, но не могут навязывать им судебные решения.

Иное дело система исполнительной власти, которая является жестко централизованной. Она имеет разветвленную систему органов и иерархическое построение по линии: местные органы исполнительной власти (местные государственные администрации) - центральные органы исполнительной власти (министерства, государственные комитеты, службы, агентства и т.п) - правительство (высший коллегиальный орган исполнительной власти) - глава исполнительной власти (традиционно - монарх, в президентских республиках - президент). Дуализм исполнительной власти, заключающийся в «распределении полномочий исполнительной власти между двумя центрами власти - президентом и правительством» $[1$, c.133], противоречит централизованной природе этой власти и является препятствием для ее эффективного функционирования, что особенно остро проявляется в случае политических расхождений между президентом и главой правительства (премьер-министром).

Поскольку правительство в той или иной форме существует в любой стране, а президент в большинстве государств конституционно так или иначе (терминологически и юридически или только юридически - через 
полномочия) идентифицируется с исполнительной властью, то это означает потенциальное существование в таких государствах дуализма исполнительной власти, при котором она не может нормально функционировать.

Дуализм исполнительной власти преодолевается или ограничивается различными конституционными способами и средствами. В президентской республике дуализм исполнительной власти исключается конституционным провозглашением президента главой исполнительной власти (это главный признак президентской республики как формы правления), означающем его верховенство по отношению к правительству (министрам) и любым другим органам и должностным лицам системы исполнительной власти. Впервые это было сделано в США: «Исполнительная власть предоставляется Президенту Соединенных Штатов Америки» (разд.1 ст.II Конституции США 1787 г.) [2]. Одними из последних по времени президентскую форму правления с провозглашением президента главой исполнительной власти конституционно учредили некоторые из республик бывшего CCCР, например: «Президент Республики Таджикистан является главой государства и исполнительной власти (Правительства)» (ч.1 ст.64 Конституции Таджикистана 1994 г.) [3]; «Президент Туркменистана является главой государства и исполнительной власти...» (ст.50 Конституции Туркменистана 1995 г.) [4].

Конституционное провозглашение президента главой исполнительной власти или принадлежности ему исполнительной власти не всегда соединяется с терминологическим закреплением президентской формы правления (например, в Таджикистане, Азербайджане). В то же время терминологическое закрепление в конституции президентской формы правления может не сопровождаться провозглашением президента главой исполнительной власти (например, в Казахстане). Но в любом случае имеет место безусловное доминирование президента в системе исполнительной власти и таким образом отсутствие ее дуализма.

В республиках с парламентарной формой правления конституционным средством преодоления дуализма исполнительной власти является институт контрасигнации, предусматривающий скрепление акта президента подписями премьер-министра и/или министра, ответственного за его исполнение, без которого акт не набирает юридической силы. Юридическое назначение контрасигнации заключается в том, чтобы снять с президента ответственность за изданный им акт и возложить ее на премьер-министра и отдельных министров, поскольку юридическая неответственность за действия в качестве главы государства является одним из основополагающих принципов конституционного статуса не только монарха, но и президента. В действительности институт контрасигнации является конституционным средством ограничения полномочий главы государства, фактического подчинения его правительству и тем самым - преодоления дуализма исполнительной власти. В парламентарных монархиях и парламентарных республиках контрасигнуются все или почти все акты главы государства.

Примером конституционного закрепления института контрасигнации может быть Австрия: «2. Все решения Федерального президента, если иное не установлено конституционным законодательством, для обеспечения их действительности должны быть скреплены подписью Федерального канцлера или компетентного федерального министра» (ч.2 ст.67 Федерального конституционного закона от 10 ноября 1920 г.) [5]. Из республик бывшего СССР парламентарную форму правления избрали Латвия и Эстония. В Конституции Латвии институт контрасигнации закреплен следующим образом: «Президент Республики за свою деятельность политической ответственности не несет. Все распоряжения Президента Республики должны быть контрасигнованы Президентом Министров (Премьер - министр Латвии В.К.) или соответствующим министром, которые вместе с этим принимают на себя всю ответственность за эти распоряжения, за исключением случаев, предусмотренных в статьях 48 и 56 Конституции» (эти случаи касаются, соответственно, роспуска парламента и формирования правительства. - В.К.) (ст.53) [6]. Конституцией Эстонии институт контрасигнации не предусмотрен, что не характерно для парламентарных республик.

Наиболее остро проблема дуализма исполнительной власти стоит при смешанной республиканской форме правления, одним из основных признаков которой он является. «Основополагающим признаком смешанной республиканской формы государственного правления, - считает украинский конституционалист В.Шаповал, является так называемый дуализм исполнительной власти. Термин «дуализм» относительно исполнительной власти первыми сформулировали французские авторы, которые с соответствующей целью используют и термин «диархия». Эти термины означают распределение полномочий в сфере исполнительной власти между президентом и правительством (кабинетом министров, советом министров), обусловливающее ее «раздвоенность» или «двуцентричность»» [7].

Дуализм исполнительной власти, как конституционное распределение полномочий по ее осуществлению между президентом и правительством, является только 
DOI: $10.7256 / 1811-9018.2015 .6 .15285$

При цитировании этой статьи сноска на доі обязательна

\section{Право и политика $6(186) \cdot 2015$}

потенциальным источником противоречий между ними и сам по себе их не вызывает. Противоречия и конфликты возникают тогда, когда позиции президента и правительства (премьер-министра) по каким-либо вопросам расходятся, особенно в случае их принадлежности к взаимно оппозиционным политическим силам. «Дуализм исполнительной власти..., - отмечают российские правоведы, - явление, имеющее место в республиках смешанного типа, где существуют «сильный» всенародно избранный президент и ответственное перед парламентом правительство. При Д.и.в. (дуализме исполнительной власти. - В.К.) исполнительная власть как бы «раздваивается» между двумя центрами: президент и его администрация, с одной стороны, и премьер-министр и правительство - с другой. Д.и.в. особенно обостренно проявляется, когда президент и премьер-министр принадлежат к соперничающим политическим партиям...» [8].

В смешанной республике президент, как правило, конституционно терминологически не идентифицируется с исполнительной властью, хотя и наделяется в сфере ее осуществления значительными полномочиями. Наиболее радикальным конституционным средством недопущения и преодоления расхождений между президентом и правительством здесь является институт политической ответственности правительства перед президентом с возможностью отставки правительства по решению президента. В этом случае правительство, в том числе и премьер-министр, в своей деятельности полностью зависят от президента и являются исполнителями проводимой им политики. Примером конституционного закрепления института политической ответственности правительства перед президентом может быть Россия: «Президент Российской Федерации: ... в) принимает решение об отставке Правительства Российской Федерации» (п. «в» ст.83); «2. Президент Российской Федерации может принять решение об отставке Правительства Российской Федерации» (п.2 ст.117) (Конституция Российской Федерации 1993 г.) [9]. В таком случае даже незначительное расхождение между премьер-министром и президентом может привести к отставке премьера, а значит, и всего правительства.

Определенный научный и практически-политический интерес представляет проблема дуализма исполнительной власти в независимой Украине, которая прошла сложный путь перехода от президентско-парламентарной к парламентарно-президентской разновидности смешанной республиканской формы правления. Конституцией Украины 1996 года в стране была учреждена президентско-парламентарная форма правления. Законом Украины «О внесении изменений в Конституцию Украины» от 8 декабря 2004 года № 2222-IV она была заменена на парламентарно-президентскую. Конституционный Суд Украины своим решением от 30 сентября 2010 года признал этот закон неконституционным, следствием чего стало восстановление в стране президентско-парламентарной формы правления. Придя к власти в результате «победы Майдана», бывшая политическая оппозиция Законом Украины «О восстановлении действия некоторых положений Конституции Украины» от 21 февраля 2014 года № 742-VII восстановила действие Закона Украины «О внесении изменений в Конституцию Украины» от 8 декабря 2004 года № 2222-IV и тем самым - парламентарно-президентскую форму правления.

Главное различие между двумя разновидностями смешанной республиканской формы правления заключается в том, кто именно - президент (президентско-парламентарная республика) или парламент (парламентарно-президентская республика) - играет определяющую роль в формировании и деятельности правительства. Полномочия Президента Украины в этом отношении целесообразно рассмотреть с точки зрения его роли в формировании правительства, политической ответственности последнего перед Президентом, влияния Президента на акты правительства и назначения руководителей местных органов исполнительной власти (председателей местных государственных администраций).

В условиях президентско-парламентарной формы правления определяющую роль в формировании правительства - Кабинета Министров Украины - играл Президент Украины. Роль парламента - Верховной Рады Украины - в этом процессе сводилась к тому, что с ее согласия Президент Украины назначал Премьерминистра Украины. Членов Кабинета Министров Украины, руководителей других центральных органов исполнительной власти, а также председателей местных государственных администраций Президент Украины назначал по представлению Премьер-министра Украины (пп. 9,10 ч.1 ст.106 Конституции Украины 1996 г.) [10]. Фактически всех этих должностных лиц Президент Украины назначал по своему усмотрению, поскольку Премьер-министр Украины во всем зависел от Президента. В соответствии с Конституцией Украины, Президент Украины «прекращает полномочия Премьер-министра Украины и принимает решения о его отставке» (п.9 ч.1 ст.106), а «Отставка Премьерминистра Украины имеет следствием отставку всего состава Кабинета Министров Украины» (ч.3 ст.115) [10]. 
Вследствие полной зависимости Премьер-министра Украины от Президента Украины противоречия в отношениях между ними в контексте дуализма исполнительной власти не проявлялись, поскольку глава государства в любое время мог уволить премьера в отставку.

Конституция Украины также установила, что Президент Украины «16) отменяет акты Кабинета Министров Украины...» (п.16 ч.1 ст.106) [10].

Положение существенно изменилось с переходом к парламентарно-президентской форме правления - определяющую роль в формировании правительства стал играть парламент. В соответствии с Законом Украины «О внесении изменений в Конституцию Украины» от 8 декабря 2004 года № 2222-IV Президент Украины:

«9) вносит по предложению коалиции депутатских фракций в Верховной Раде Украины, сформированной в соответствии со статьей 83 Конституции Украины, представление о назначении Верховной Радой Украины Премьер-министра Украины в срок не позже чем на пятнадцатый день после получения такого предложения;

10) вносит в Верховную Раду Украины представление о назначении Министра обороны Украины, Министра иностранных дел Украины» (пп.9,10 ч.1 ст.106) [11].

Статья 83 Конституции Украины предусматривает, что «В Верховной Раде Украины по результатам выборов и на основе согласования политических позиций формируется коалиция депутатских фракций, в состав которой входит большинство народных депутатов Украины от конституционного состава Верховной Рады Украины». Президент Украины, таким образом, может внести в Верховную Раду Украины для назначения Премьер-министром Украины не любую кандидатуру по своему усмотрению, а только предложенную ему парламентским большинством.

К полномочиям Верховной Рады Украины относится: «12) назначение по представлению Президента Украины Премьер-министра Украины, Министра обороны Украины, Министра иностранных дел Украины, назначение по представлению Премьер-министра Украины других членов Кабинета Министров Украины, Председателя Антимонопольного комитета Украины, Председателя Государственного комитета телевидения и радиовещания Украины, Председателя Фонда государственного имущества Украины, освобождение указанных лиц от должности...» (п.12 ч.1 ст.85) [11].

Порядок назначения председателей местных государственных администраций остался прежним - они назначаются Президентом по представлению Премьерминистра. Однако произошли существенные изменения в институте политической ответственности правительства перед главой государства. Конституционная реформа 2004 года сохранила институт политической ответственности Кабинета Министров Украины перед Президентом Украины: «Кабинет Министров Украины ответственный перед Президентом Украины и Верховной Радой Украины, подконтрольный и подотчетный Верховной Раде Украины в пределах, предусмотренных этой Конституцией» (ч.2 ст.113) [11], но отменила право Президента Украины принимать решение об отставке Премьер-министра Украины, а следовательно, и всего состава Кабинета Министров Украины. Теперь Президент Украины может только предложить парламенту рассмотреть вопрос об ответственности правительства, решение которого остается за парламентом: «Верховная Рада Украины по предложению Президента Украины или не менее одной трети народных депутатов Украины от конституционного состава Верховной Рады Украины может рассмотреть вопрос об ответственности Кабинета Министров Украины большинством от конституционного состава Верховной Рады Украины» (ч.1 ст.87) [11].

Отмена права Президента Украины принимать решение об отставке Премьер-министра Украины сделала последнего относительно независимым от главы государства, что способствовало обострению отношений между ними. Особенно наглядно это проявилось после внеочередных парламентских выборов, состоявшихся 30 сентября 2007 года. По результатам выборов в Верховной Раде Украины были сформированы коалиция депутатских фракций при участии фракций «Блок Юлии Тимошенко» и блока «Наша Украина - Народная самооборона», а на ее основе в декабре 2007 года - новый состав Кабинета Министров Украины во главе с Премьер-министром Ю.Тимошенко.

Президент Украины В.Ющенко не мог смириться с ограничением его полномочий конституционной реформой 2004 года и всячески стремился по-прежнему влиять на Верховную Раду и руководить Кабинетом Министров, чему сопротивлялась Премьер-министр Ю.Тимошенко. В качестве одного из средств давления на правительство В.Ющенко избрал Совет национальной безопасности и обороны Украины, являющийся координационным органом по вопросам национальной безопасности и обороны при Президенте Украины. Поскольку решения СНБО Украины принимаются под определяющим воздействием Президента Украины, являющегося его Председателем, и вводятся в действие указами Президента, то В.Ющенко стремился через эти решения влиять на деятельность Кабинета Министров Украины. 
DOI: $10.7256 / 1811-9018.2015 .6 .15285$

При цитировании этой статьи сноска на dоі обязательна

\section{Право и политика $6(186) \cdot 2015$}

В соответствии с Конституцией Украины акты Президента Украины, касающиеся деятельности СНБО, скрепляются подписями Премьер-министра Украины и министра, ответственного за акт и его исполнение (ч.4 ст.106) [11]. Премьер-министр Ю.Тимошенко отказывалась контрасигновать соответствующие акты Президента В.Ющенко, ссылаясь на то, что Конституция Украины прямо не обязывает ее это делать. А без контрасигнации такие акты не набирали юридической силы.

Разногласия между главой государства и премьером по поводу контрасигнации в разное время пытались разрешить через принятие все новых законов о Кабинете Министров Украины. Причем один из таких законов устанавливал, что «9. В случае если Премьер-министр Украины, министр, ответственный за акт и его исполнение, считают невозможным скрепление подписями акта Президента Украины, они возвращают такой акт с изложением в сопроводительном письме мотивов своих решений в сроки, установленные этой статьей для скрепления акта Президента Украины» (ч.9 ст.27) [12], а другой - что «3. Премьер-министр Украины и министр, ответственный за акт Президента Украины... и за исполнение такого акта, обязаны скрепить его своими подписями в пятидневный срок со дня поступления акта для скрепления» (ч.3 ст.25) [13].

В соответствии с конституционной реформой 2004 года Президент Украины утратил также право отменять акты Правительства: теперь он только «15) приостанавливает действие актов Кабинета Министров Украины по мотивам несоответствия этой Конституции с одновременным обращением в Конституционный Суд Украины относительно их конституционности» (п.15 ч.1 ст.106) [11].

Конституционная реформа 2004 года, значительно ограничив полномочия Президента Украины в сфере исполнительной власти, вместе с тем, отменив его право принимать решение об отставке премьера, создала потенциальные предпосылки для возникновения противоречий и конфликтов в отношениях между ними. С избранием Президентом Украины П.Порошенко и формированием в Верховной Раде Украины по результатам внеочередных выборов, состоявшихся 26 октября 2014 года, коалиции депутатских фракций при определяющем участии Партии «Блок Петра Порошенко» и Политической партии «Народный фронт», лидером которой является нынешний Премьер-министр Украины А.Яценюк, серьезных расхождений между главой государства и премьером пока что удается избегать, во всяком случае, внеше. Что не исключает возможности их появления в будущем.

Таким образом, дуализм исполнительной власти, как конституционное распределение полномочий по ее осуществлению между президентом и правительством, противоречит централизованному характеру этой власти и может порождать противоречия и конфликты между президентом и правительством (премьер-министром), отрицательно влияющие на эффективность государственной власти. В президентской республике дуализм исполнительной власти не допускается конституционным провозглашением президента главой исполнительной власти и подчинением ему правительства. В парламентарной республике конституционным средством ограничения дуализма исполнительной власти (реальных полномочий президента) является институт контрасигнации. Общим направлением преодоления дуализма исполнительной власти в смешанной республике является ограничение конституционных полномочий президента по ее осуществлению. Конкретными конституционными средствами преодоления или ограничения дуализма исполнительной власти в смешанной республике являются институт политической ответственности правительства перед президентом с возможностью отставки премьер-министра по решению президента и институт контрасигнации с правом премьер-министра контрасигновать акты президента по своему усмотрению.

\section{Библиография}

1. Шляхтун П.П. Конституційне право : словник термінів / П.П.Шляхтун. - К. : Либідь, 2005. - 568 с.

2. Конституция Соединенных Штатов Америки // Конституции зарубежных государств : учебное пособие / сост. В.В.Маклаков. - 4-е изд., перераб. и доп. - М. : Волтерс Клувер, 2003. - 624 с.

3. Конституция Республики Таджикистан. - Режим доступа: http://parlament.tj/ru//index.php?option=com_ content\&view $=$ article\&id $=57$

4. Конституция Туркменистана. - Режим доступа: http://www.ambturkm.org.ua/index.php?option=com_content\&view=articl e\&id=221temid $=31$

5. Конституция Австрийской Республики. Федеральный конституционный закон от 10 ноября 1920 года // Конституции государств Европы : В 3 т. / Л.А.Окуньков (общ. ред. и вступ. ст.); Институт законодательства и сравнительного правоведения при Правительстве Российской Федерации. - М. : Норма, 2001. - Т.1.

6. Конституция Латвийской Республики // Там же. - Т.2. 
7. Шаповал В.М. Сучасний конституціоналізм : монографія / В.М.Шаповал. - К. : Юридична фірма «Салком»; Юрінком Інтер, 2005. - $560 \mathrm{c}$.

8. Большой юридический словарь / под ред. А.Я.Сухарева, В.Д.Зорькина, В.Е.Крутских. - М. : ИНФРА-М, 1998. - 790 с.

9. Конституция Российской Федерации // Конституции государств Европы : В 3 т. / Л.А.Окуньков (общ. ред. и вступ. ст.); Институт законодательства и сравнительного правоведения при Правительстве Российской Федерации. - М. : Норма, 2001. - Т.3.

10. Конституція України. Прийнята на п’ятій сесії Верховної Ради України 2-го скликання 28 червня 1996 року // Відомості Верховної Ради України. - 1996. - № 30. - Ст.141.

11. Закон України «Про внесення змін до Конституції України» від 8 грудня 2004 року № 2222-IV // Там же. - 2005. № 2. - Ст.44.

12. Закон України «Про Кабінет Міністрів України» від 21 грудня 2006 року № 514-V // Голос України. - 2007. - 2 лютого.

13. Закон України «Про Кабінет Міністрів України» від 7 жовтня 2010 року № 2591-VI // Голос України. - 2010. -13 жовтня.

\section{References (transliterated):}

1. Shlyakhtun P.P. Konstitutsiine pravo : slovnik terminiv / P.P.Shlyakhtun. - K. : Libid', 2005. - 568 s.

2. Shapoval V.M. Suchasnii konstitutsionalizm : monografiya / V.M.Shapoval. - K. : Yuridichna firma «Salkom»; Yurinkom Inter, 2005. $-560 \mathrm{~s}$. 